RAD Conference Proceedings, vol. 2, pp. 11-14, 2017

www.rad-proceedings.org

a.00001 tht

\title{
SURFACE IRRADIATION OF CHICKEN EGGS BY NANOSECOND ELECTRON BEAM
}

\author{
S.Yu. Sokovnin ${ }^{1,2}{ }^{*}$, R.A. Vazirovi,3, M.E. Balezin², A.S. Krivonogova1 \\ ${ }^{1}$ Ural State Agrarian University, Yekaterinburg, Russia \\ 2Institute of Electrophysics UB RAS, Yekaterinburg, Russia \\ 3Ural Federal University, Yekaterinburg, Russia
}

\begin{abstract}
The irradiation exposure experiments were carried out by means of the pulsed repetitive nanosecond accelerator URT-O.5 (electron energy of up to $500 \mathrm{keV}$, a pulse width of $50 \mathrm{~ns}$, pulse repetition rate of up to 20opps). The determination of the distribution of the absorbed dose (AD) in the depth in the polyethylene was conducted by a gray wedge. The measurement of the electron beam AD on the surface of the shell (removed from the eggs) and under the shell, as well as beneath the absorber layer (polyethylene 80 microns thick) was also performed by the film dosimeter. Thermoluminescent dosimeters, TLD-50o, were used to determine the distribution of the bremsstrahlung $A D$ inside chicken eggs. These results lead to the conclusion that the irradiation of an electron beam with the AD level of $5 \mathrm{kGy}$ is sufficient for complete disinfection on the surface of an egg. The AD inside of it will not exceed $8 \mathrm{cGy}$ because of bremsstrahlung.
\end{abstract}

Key words: Disinfection, electrons, bremsstrahlung, dosimetry, radiation treatment, Salmonella, chicken egg

DOI: $10.21175 /$ RadProc.2017.03

\section{INTRODUCTION}

Foods must be safe for the consumer. One of the hazards is microbiological contamination. The requirements for microbial contamination include monitoring of both the overall microbiological contamination and the presence / absence of the certain types of especially dangerous pathogens. The permissible level of microbial contamination is achieved by a complex of sanitary and hygienic conditions at the production and packaging of food products.

At present, virtually the only way to reduce the microbial contamination of foods is the heat treatment. However, thermal sterilization leads to irreversible changes in the properties of raw materials, which is not always acceptable. Applied chemical methods, such as salting, sugaring, etc. lead to the same result, and use a lot of preservatives. Therefore, the heat pasteurization is widely used to increase the shelf life of foods, followed by cooling to temperatures at which the multiplication of microorganisms is difficult.

It is known that one of the indicators of the quality of the eggs is the purity of the shell. However, the presence of dirt (i.e., microorganisms), not only makes the appearance of the eggs unattractive, but also facilitates the penetration of microorganisms through pores in the shell egg into its content, which leads to rapid deterioration of eggs, and makes them hazardous to Salmonella infection, as well.
Wash improves the appearance of the eggs, but sharply reduces their storage stability, so it is usually used before breaking up the eggs in the food industry [1]. Such a washing results in the opening of pores in the shell, through which the microorganisms can penetrate the egg. It also requires a hot water flow $(\sim 800 C)$ and chemically disinfecting substances $(3.2 \%$ hydrogen peroxide), which greatly increases contamination of nature by toxic waste [2].

An alternative is radiation sterilization, due to the universality of the harmful effects of ionizing radiation on any biological objects. In this way, the absorbed dose (AD) of radiation sterilization (regardless of the type of radiation) does not exceed $25 \mathrm{kGy}$ [3].

However, the irradiation of the foods may be accompanied by a variety of chemical reactions which may transform the organoleptic properties of the products. Thus, it is necessary to set the limits of $\mathrm{AD}$ for irradiation of various products.

For example, for fresh eggs, a level of $\mathrm{AD} \leq 3 \mathrm{kGy}$ is recommended, which is close to the $\mathrm{AD}$ level for inactivation of the bacteria of the Salmonella group [4]. Irradiated foods are marked with a special sign "radura", so that the buyer could choose whether to use irradiated products or nor. Unfortunately, the radiation phobia is of great importance for the consumer choice.

To solve the problems of microbiological contamination of eggs and the consumer sentiment, in our view, the following approaches look promising.

* sokivnin@iep.uran.ru 
Firstly, by proper electron energy selection, to choose such an $\mathrm{AD}$ distribution profile within the product, that will destroy, upon irradiation, all kinds of microbes, including the pathogenic ones both on the shell surface and in its pores as well as in the air chamber up to the under-shell membranes. In that way, there will be practically no exposure of the protein itself to the accelerated electrons.

Secondly, the ozone will be produced under the irradiation, which will also contribute to the disinfection of the surface, especially by irradiation of the eggs sealed in plastic containers. It is possible, to sterilize the eggs after packaging by the radiation itself as well as by the creation of ozone at a concentration levels lethal to microorganisms in the packaging radiation-chemical sterilization [5]. At the same time, it is possible to select the $\mathrm{AD}$ distribution profile within the egg in such a way that, its protein is not irradiated by electrons, at all. It is important that the presence of sealed plastic containers allows us to solve the problem of re-semination of eggs during storage.

Both ways have their merits. Moreover, in the real technological process, both ways can be combined in different proportions.

The disadvantage of irradiation sterilization is its high cost and heightened risk for the working staff. This risk can be significantly reduced by optimizing the radiation source.

At present, nanosecond electron accelerators for the technologies [6] which significantly reduce the costs of the radiation source itself, as well as the costs of the personnel radiation protection have been developed and produced.

Furthermore, a stronger bactericidal effect of the nanosecond electron beam (NEB) is known [7]. That will allow to reduce the $\mathrm{AD}$ magnitude of the electron beam 2-3 times, which will increase the efficiency of the method while leaving the energy consumption and material costs the same.

A feature of the NEB spectrum is the presence of a much greater body of the low-energy electrons, which occur at the acceleration at the pulse fronts of the accelerating voltage. For our purposes, this is a positive feature, because it allows us to obtain the desired $\mathrm{AD}$ distribution profile within the product (Figure 1).

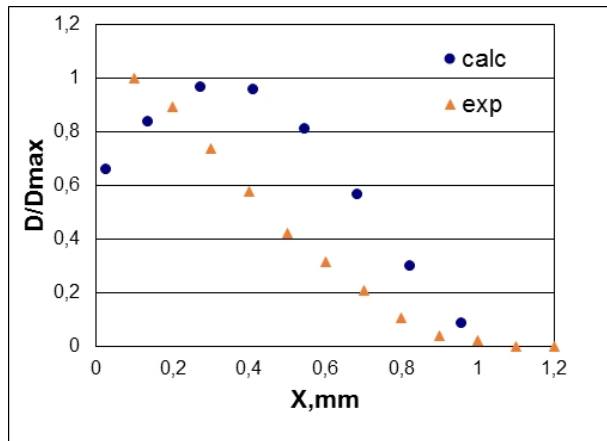

Figure 1. Measured experimentally and calculated distribution of absorbed dose in the depth in the polyethylene

Unfortunately, it is impossible to completely avoid irradiation of the egg protein since bremsstrahlung is induced by absorption of the electrodes which makes a major contribution to the $\mathrm{AD}$, created inside the egg.

Thus, the aim of this study was to investigate the profile of $\mathrm{AD}$ distribution on the surface and inside the egg from the electron beam and bremsstrahlung.

\section{THE METHODOLOGY AND EXPERIMENT RESULTS}

The exposure experiments were carried out by the pulsed repetitive nanosecond accelerator URT-0.5 [8] (electron energy up to $500 \mathrm{keV}$, pulse width about 50 ns, pulse repetition rate up to $200 \mathrm{pps}$ ). At the first phase the measurement of the absorbed dose distribution in depth in polyethylene (analogue of biological tissue) was carried out by a gray wedge. $\mathrm{AD}$ was tested by a film dosimeter $\mathrm{CO} \mathrm{AD}(\mathrm{F}) \mathrm{R}-5 / 50$ [9], covered with polythene layers of varying thickness (up to 600 microns). $\mathrm{AD}$ measurements on the film dosimeters were conducted by determining the density of darkening of the spectrophotometer PE 5400VI, followed by recalculation of calibration lines. During the experiments, the accelerator was operating at the regimes of a charging voltage of 25 and $30 \mathrm{kV}$. Electron beam dosimetry results are shown in Figure 2.

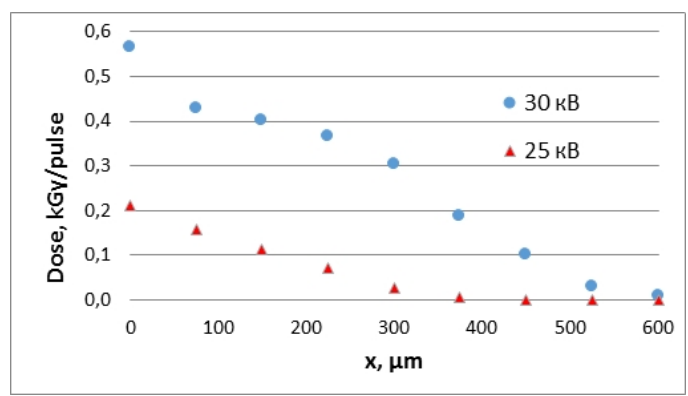

Figure 2. Distribution of the electron beam $\mathrm{AD}$ in the depth in the polyethylene at a different charging voltage on the accelerator URT-0.5

Besides that, using the film dosimeter, a measurement of the electron beam AD on shell surface (removed from the egg) and under the shell as well as beneath the absorber layer (polyethylene of 80 microns thick) was performed (Figure 3). The sample was placed in a plastic container to save the geometry used for the irradiation of eggs. The results of dosimetry at a different charging voltage are shown in Table 1.

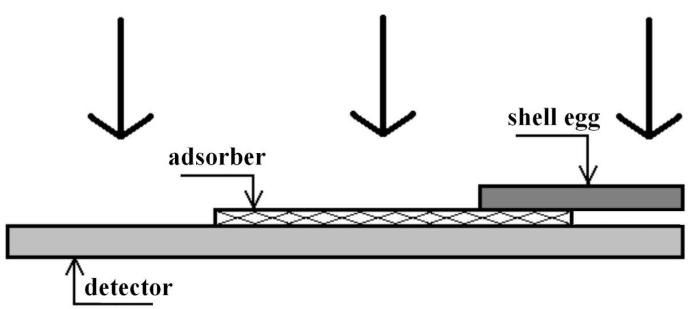

Figure 3. The geometry of the irradiation under the electron beam dosimetry

To determine the distribution of $\mathrm{AD}$ bremsstrahlung inside chicken egg thermoluminescent 
dosimeters (TLD) TLD-500 (diameter of $5 \mathrm{~mm}$ and a thickness of $1 \mathrm{~mm}$ ) based on aluminum oxide doped with carbon were used [10]. The dosimeters were placed in sections of boiled eggs (or cut lengthwise, or crosswise), in such a way that it was possible to determine the $\mathrm{AD}$ distribution in various points of the biological object (Figure 4).

$\mathrm{AD}$ measurement was carried out by a hardware system to highlight TLD dosimeters. Thermoluminescence lines were recorded by a special automated apparatus at a heating rate of $2 \mathrm{~K} / \mathrm{s}$ [11]. The signal was detected by a photomultiplier FEU-142 with reduced sensitivity to thermal radiation of the heater, the maximum temperature of which could be $1200 \mathrm{~K}$.

Table 1. Measurement results of the electron beam AD

\begin{tabular}{|c|l|c|c|c|}
\hline \multirow{2}{*}{ № } & \multirow{2}{*}{$\begin{array}{c}\text { Place of detector } \\
\text { arrangement }\end{array}$} & \multicolumn{3}{|c|}{$\begin{array}{c}\mathrm{AD}, \mathrm{Gy} / \text { pulse at a } \\
\text { different charging voltage }\end{array}$} \\
\cline { 3 - 5 } 1 & $30 \mathrm{kV}$ & $25 \mathrm{kV}$ & $20 \mathrm{kV}$ \\
\hline & $\begin{array}{l}\text { On the lid of a plastic } \\
\text { container outside }\end{array}$ & 583 & 505 & 173 \\
\hline 2 & $\begin{array}{l}\text { On the surface of the } \\
\text { shell }\end{array}$ & 195 & 170 & 8 \\
\hline 3 & Under the shell & 8.43 & $-*$ & - \\
\hline 4 & $\begin{array}{l}\text { Under the shell and } \\
\text { absorber layer }\end{array}$ & 0.61 & - & - \\
\hline
\end{tabular}

${ }^{*} \mathrm{AD}$ value is below the threshold of detector sensitivity
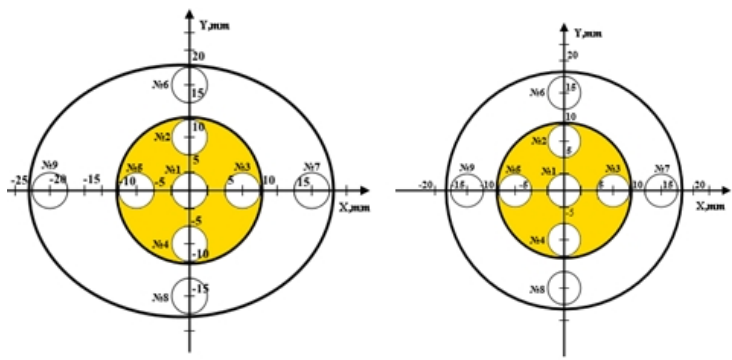

Figure 4. Location of TLD dosimeters (5 $\mathrm{mm}$ in diameter) at vertical (right) and the horizontal section of the chicken egg

Table 2. Measurement results of bremsstrahlung AD inside the egg

\begin{tabular}{|c|c|c|}
\hline \multirow{2}{*}{$\begin{array}{c}\text { Dosimeter } \\
\text { No } \\
\text { (Figure 4) }\end{array}$} & \multicolumn{2}{|c|}{ AD, cGy/pulse } \\
\cline { 2 - 3 } & horizontal section & vertical section \\
\hline 1 & 0.13 & 0.16 \\
\hline 2 & 0.25 & 0.15 \\
\hline 3 & 0.18 & 0.17 \\
\hline 4 & 0.17 & 0.13 \\
\hline 5 & 0.15 & 0.14 \\
\hline 6 & 0.18 & 0.18 \\
\hline 7 & 0.31 & 0.21 \\
\hline 8 & 0.15 & 0.15 \\
\hline 9 & 0.17 & 0.26 \\
\hline
\end{tabular}

\section{DISCUSSION OF THE MEASUREMENT RESULTS}

As one can see from Figure 2, by varying the charging voltage of the accelerator, it is possible to choose the depth of the electrons' penetration, in order to limit the exposure of the shell $(0.3-0.4 \mathrm{~mm})$ and the under-shell protein membranes $(\sim 70 \mu \mathrm{m})$ [1].

It should be noted that the shell consists of calcium carbonate with a density $\left(2.74-2.83 \mathrm{~g} / \mathrm{cm}^{3}\right)$ and an atomic number close to those of aluminum. However, the shell is a porous structure and the passage of electrons through it will be a complicated process.

The data of Table 1 shows that at the charging voltage of $30 \mathrm{kV}$, it is possible to obtain the desired profile of the absorbed dose distribution in the depth at which the electron irradiation does not penetrate below the absorber layer, simulating the under-shell egg membranes (Figure 3).

The measurement results showed that the bremsstrahlung $\mathrm{AD}$ inside the egg does not exceed o.31 cGy / pulse and at the yolk not more than $0.2 \mathrm{cGy} /$ pulse (Table 2).

At the same time the electron beam $\mathrm{AD}$ on the surface of eggs was $0.2 \mathrm{kGy} \mathrm{/} \mathrm{pulse} \mathrm{(see} \mathrm{Table} \mathrm{1).}$ Consequently, at $\mathrm{AD}=5 \mathrm{kGy}$, which can be acquired by 25 pulses and is sufficient to disinfect the surface of eggs from Salmonella, bremsstrahlung AD in protein will not exceed $8 \mathrm{cGy}$ and in yolk $5 \mathrm{cGy}$.

This $\mathrm{AD}$ value should not lead to the biological transformations of the biological tissue, but rather to be within the $\mathrm{AD}$ range that has a stimulating effect on the living organisms (radiation hormesis) [10].

Bremsstrahlung yield calculations under irradiation surface of the egg $(4.5 \mathrm{~cm}$ in diameter) by electron beam from an accelerator URT-0.5 (the electron current density per pulse $\sim 3 \mathrm{~A} / \mathrm{cm}^{2}$ ), were made according to the Foster's formula [12] and in accordance with the biological protection calculation method for electron accelerators [13]. The results show that the $\mathrm{AD}$ is in the range of $0.11-0.15 \mathrm{cGy} /$ pulse. Additional irradiation of the eggs is created by the electron beam bremsstrahlung, being absorbed by the radiation-absorbing accelerator output structures, as well as by the scattered radiation.

\section{CONCLUSION}

The results obtained lead to the conclusion that the irradiation by an electron beam with $\mathrm{AD}$ level of $5 \mathrm{kGy}$ is sufficient for the complete disinfection on the surface of an egg. At the same time the AD inside of the egg will not exceed 8 cGy because of bremsstrahlung. This AD value should not lead to biological transformations of the protein and the yolk.

Acknowledgement: This work was supported by the Russian Science Foundation, project No 16-16-04038.

\section{REFERENCES}

1. В. В. Гуслянников, М. А. Подлегаев, Технология мяса птиць и яйцепродуктов, Москва, Россия: Пищевая промышленность, $1979 \quad$ г. (V. V. Guslyannikov, M. A Podlegaev, Technology of 
poultry meat and egg products $A M$, Moscow, Russia: Food Industry, 1979.)

2. А. П. Лищук «Обеззараживание куриных яиц и яйцепродуктов (меланж и яичный порошок) от сальмонелл» диссертация на соискание ученой степени кандидата ветеринарных наук (16.00.06)/ Лищук Андрей Петрович; Российская академия сельскохозяйственных наук. - Москва, 2002 - 177 с. (A. P. Lishchuk "Disinfection of eggs and egg products (egg powder and egg products) from Salmonella," Ph.D. dissertation, Veterinary Sciences, Russian Academy of Agricultural Sciences, Moscow, Russia, 2002.)

3. М. А. Туманян, Д.А. Каушанский, Радиационная стерилизация, Москва, Россия: Медицина, 1974. стр. 304. (M. A. Tumanyan, D. A. Causeni, Radiation sterilization, Moscow, Russia: Medicine, 1974. p.304.)

4. European Food Safety Authority, "Statement summarising the Conclusions and Recommendations from the Opinions on the Safety of Irradiation of Food adopted by the BIOHAZ and CEF Panels," EFSA Journal, vol. 9, no. 4, pp. 2107-1 - 2107-98, Mar. 2011. DOI: 10.2903 / j.efsa.2011.2107

5. Yu. A. Kotov, S. Yu. Sokovnin. "Overview of the application of nanosecond electron beams for radiochemical sterilization," IEEE Transactions on Plasma Science, Special Issue, vol. 28, no. 1, pp. 133136, Feb. 2000.

DOI: $10.1109 / 27.842883$

6. S. Yu. Sokovnin, M. E. Balezin "Production of nanopowders using nanosecond electron beam," Ferroelectrics, vol. 436, no. 1, pp. 108-111, Dec. 2012. DOI: $10.1080 / 10584587.2012 .731330$ DOI: $10.1080 / 10584587.2012 .730951$

7. S. Yu. Sokovnin, Yu. A. Kotov, S. N. Rukin, G. A. Mesyats, "Research of the effects of Impulse frequency electron beams on microorganisms in aqueous solutions," Russian Journal of Ecology, vol. 27, no. 3, 1996. pp. 214-216.
8. Yu. A. Kotov, S. Yu. Sokovnin, M. E. Balezin, "YPT-0.5 repetitive-pulse nanosecond electron accelerator," Instr. and Exp. Tech., vol. 43, no. 1, pp. 102-105, Jan. 2000.

DOI : 10.1007 / BFo2759009

9. R. A. Abdulov, V. V. Generalova "Monitoring maintenance of radiation-technological processes in Russia," High Energy Chemistry, vol. 36, no. 1, pp. 2633, Jan. 2002. DOI: 10.1023/A:1013644410792

10. I. I. Mil'man, E. V. Moiseǐkin, S. V. Nikiforov, S. V. Solov'ev, I. G. Revkov, E. N. Litovchenko, "The role of deep traps in luminescence of anion-defective $\alpha_{-} \mathrm{Al}_{2} \mathrm{O}_{3}$ : C crystals," Physics of the Solid State, vol. 50, no. 11, pp 2076-2080, Nov. 2008. DOI: 10.1134 / S1063783408110127

11. А. М. Кузин, "Проблема малых доз и идеи гормезиса в радиобиологии," Радиобиология, том. 31, вып. 1., cc. 16-21, 1991. (A. M. Kuzin, "The problem of low doses and hormesis ideas in radiobiology," Radiobiology, vol. 31, no. 1, pp. 16-21, 1991.)

12. D. W. Forster, M. Goodman, G. Herbert, J. C. Martin, T. Stor, "Electron beam diagnostics using X-rays," in $J$. C. Martin on Pulsed Power, vol. 3, T. H. Martin, M. Williams, M. Kristiansen, Eds., 1st ed., New York, (NY), USA: Springer US, 1996, ch. 11, pp. $375-412$.

DOI: $10.1007 / 978-1-4899-1561-0 \_31$

13. Правила работы с радиоактивными веществами и другими источниками ионизирующих излучений в учреждениях и организациях Академии наук СССР, Академия наук СССР, Москва, СССР: Наука, 1984, c. 303. (Rules for working with radioactive substances and other sources of ionizing radiation at the institutions and organizations of the Academy of Sciences of USSR, Academy of Sciences of USSR, Moscow, USSR: Nauka, 1984, p. 303.) 